\title{
DAZ1 wt Allele
}

National Cancer Institute

\section{Source}

National Cancer Institute. DAZ1 wt Allele. NCI Thesaurus. Code C124848.

Human DAZ1 wild-type allele is located in the vicinity of Yq11.223 and is approximately 70 $\mathrm{kb}$ in length. This allele, which encodes deleted in azoospermia protein 1, is a candidate for the human Y-chromosomal azoospermia factor (AZF) and plays a role in germ-cell progression to meiosis and the formation of haploid germ cells. 